\title{
Students' grammatical error analysis in the recount text translation
}

\author{
Nilam Puspita Sari ${ }^{1}$ \\ Gede Eka Putrawan² \\ Rafista Deviyanti ${ }^{3}$ (i) \\ ${ }^{123}$ English Education Study Program, University of Lampung, Bandar Lampung, Indonesia
}

\begin{abstract}
This research aims to determine the types of grammatical errors that students make the most and least frequently, as well as the causes of those errors, using the Surface Strategy Taxonomy that was identified in students' recount text translation. The participants in this study were SMAN 1 Pringsewu first-graders in the academic year 2020/2021. This research adopted a descriptive qualitative method by using a translation task and questionnaire for the instruments. According to the Surface Strategy Taxonomy, the students made all types of errors: omission, addition, misformation, and misordering. In recount text translation based on Surface Strategy Taxonomy, the most common error made by students was misformation, whereas the least frequent error type was misordering. Problems with the target language, mother-tongue interference, a lack of eagerness to learn the target language, a lack of confidence, and the absence of error feedback from the teacher were all possible causes of those errors. This indicates that the students' English grammar understanding was still limited. Therefore, the English teacher is expected to solve it by providing appropriate teaching methods and materials to reduce errors.
\end{abstract}

\section{KEYWORDS}

Error analysis; surface strategy taxonomy; translation

Received: 15 June 2021

Accepted: 28 June 2021

Published: 29 June 2021

\section{Introduction}

In Indonesia, students who study English as a foreign language (EFL) often face some difficulties. They are required to have good knowledge of four basic language skills; reading, listening, writing, and speaking (Khoirunida, 2019) because when composing a text, they are required to pay careful attention to five fundamental components of the writing process: form, content, style, grammar, and mechanics (Kumala, Aimah, \& Ifadah, 2018). However, writing in English is not an easy matter that needs little effort for students since the linguistic structures of English differ from that of their first language (L1) (Dang, 2019). Thus, they have more possibility to make grammatical errors when writing in English.

Grammar is a set of rules that govern the standard arrangement and relationship of words in a sentence that becomes meaningless if two other dimensions, semantics and pragmatics, are absent (Brown, 2001). Making mistakes is a normal part of learning. People who are learning a second or foreign language must first make errors to learn the language (Dulay, Burt, \& Krashen, 1982).

Writing in English is entirely different from writing in Indonesian. In Indonesian, there are no tenses; a verb appears in the same form at all times, whereas English has a precise order and rule to follow when constructing the sentences according to tenses. Thus, students misuse verbs in writing in English since tenses are not a feature in Indonesian. Although they have been learning English since they were in elementary school, they still find it hard to translate from Indonesian into English (Khoirunida, 2019), especially when translating past events into English (Anjarani \& Indahwati, 2019). In addition, (Koman, Hartono \& Yuliasri, 2019) found that students made grammatical errors when translating a text from Indonesian into English in terms of word choice, verb changes, and punctuation. Kumala et al's. (2018) findings suggest that these errors were made unconsciously, and students have reasons to make such errors, e.g. carelessness, first language interference, and translation.

In this study, we analysed the grammatical errors by using a translation task of recount text from Indonesian into English. Moreover, we used an open-ended questionnaire to investigate the possible causes of students' grammatical errors and students' awareness about their errors. This research is expected to have significant theoretical and practical benefits as a result of its conclusion. Theoretically, the findings of this study will be used to enhance and expand on previous studies. While it can be used as a tool for English teachers to reduce student errors, it can also be used as feedback for the student to develop their grammatical understanding and writing weaknesses. 


\section{Literature Review \\ Grammatical errors}

Grammar refers to the rules in how a language's sentences are formed and affects the meaning of the sentence (Thornbury, 1999; Ur, 1996). Students are required to master grammar to enable them to correct the sentences in conversation, both in written and spoken forms. The error relates to students' incorrect action from being able to reconstruct their knowledge of a language (Corder, 1981). Students' errors provide evidence of the system of the language that they are using. The grammatical error concerns the principles of morphology handling in word structure and syntax handling in the phrase, clause, sentence, and paragraphs (James, 2013). Grammatical errors need to be analysed due to the fact that it can investigate how learners acquire a second language (Ellis, 1997). Error analysis is an efficient technique to help the teacher in developing learning methods and strategies.

\section{Recount text}

Recount text is used to retell a story that occurred in the past in the order in which it occurred (Anderson and Anderson, 1997). The objective of a recount text is to tell what actually happened to the reader in chronological order. Recount has three schematic structures, according to (Anderson and Anderson, 1997). Orientation, events, and reorientation are the three. The orientation is found in the first paragraph of the recount text. It contains background information regarding the recount text, such as who was engaged in the story, what happened when, and where the events occurred. In chronological order, events describe what occurred. Because those occurrences are at the centre of the story, it is the most significant element of the recount text. This is followed by a series of paragraphs that describe all of the previous events in the story. The recount passages come to an end with reorientation. This final section can include the story's conclusion and comments. Proper nouns, descriptive words, past tense use, and sequence words are the four language features of recount texts, according to (Anderson and Anderson, 1997).

\section{Translation}

Translation is the process of transferring the meaning of the source language into the target language, which the translator performs based on an interpretation and the target language's most appropriate equivalence material (Catford, 1965; Newmark, 1988; Venuti, 1995). According to (Wahyono and Yuliasri, 2019), to do a decent translation, the translator must know the source language and, more importantly, the target language practically well. As a result, students must be fluent in both the target and source languages when translating. There are two types of translation, according to (Larson, 1998): form-based translation or literal translation and meaning-based translation or idiomatic translation. Because literal translation uses word-by-word translation, it frequently sounds unnatural, but idiomatic translation uses the natural forms of the target language to sound more natural. According to (Nida and Taber, 1982), the translation process is separated into three stages: analysis, transfer, and restructuring. Translators must analyse the grammatical relationship as well as the meaning of the morpheme utilised in the text during the analysis step. The method of transmitting the source material into the target language is included in the transfer. The translator can restructure the text after it has been transferred to ensure that it is accepted by the target language.

\section{Methods}

This research adopted a descriptive qualitative approach when describing and analysing the grammatical errors produced by the students when translating the text. We described the students' errors in this study using a simple formula that calculates errors in percentage forms. Then, each sample of errors was qualitatively described. Surface Strategy Taxonomy was used to analyse and categorise the data collected. The study's participants were first-grade students at SMAN 1 Pringsewu in the academic year 2020/2021. Three students were chosen as samples from each of the ten classes, with a total of 30 students.

The translation task was used to collect the data on the errors made by the students. The task's main topic was on recount text. It was about "My holiday in Yogyakarta" which consisted of four paragraphs, with 194 words in 20 sentences. The students translated the text on Quizizz within 80 minutes. To get the possible causes of errors, the researcher used an open-ended questionnaire consisting of 10 questions to look at the possible causes of errors and 20 questions to investigate the students' awareness about their errors.

The researcher took the following steps in analysing the data on student errors: identifying errors, classifying errors, calculating errors, tabulating the errors, and explaining errors. The data collected from the questionnaires were analysed qualitatively by coding and categorising the data. Then, the data were presented in the pie charts to show the frequency of the students' different answers to each question. In interpreting, the researcher compared the findings to relevant theories or other research findings. 


\section{Results}

\section{Types of errors found in students' translation}

Concisely, the students made an omission, addition, misformation, and misordering errors in their translation, classified using the Surface Strategy Taxonomy.

Frequencies of students' grammatical errors based on surface strategy taxonomy

In table below, the frequency of each error type classified in this taxonomy is shown.

Table 1. Students' errors frequencies based on surface strategy taxonomy

\begin{tabular}{|c|c|c|c|c|}
\hline No. & $\begin{array}{c}\text { Surface Strategy } \\
\text { Taxonomy }\end{array}$ & Component & Frequency & Percentage (\%) \\
\hline 1 & Omission & & 33 & $11.9 \%$ \\
\hline \multirow[t]{4}{*}{2} & \multirow[t]{4}{*}{ Addition } & Double marking & 12 & $4.3 \%$ \\
\hline & & Regularisation & 2 & $0.7 \%$ \\
\hline & & Simple addition & 34 & $12.2 \%$ \\
\hline & & & 48 & $17.2 \%$ \\
\hline \multirow{4}{*}{3} & \multirow{4}{*}{ Misformation } & Regularization & 97 & $34.9 \%$ \\
\hline & & Archi-form & 28 & $10.1 \%$ \\
\hline & & Alternating & 52 & $18.7 \%$ \\
\hline & & & 177 & $63.7 \%$ \\
\hline \multirow[t]{2}{*}{4} & Misordering & & 20 & $7.2 \%$ \\
\hline & Total & & 278 & $100 \%$ \\
\hline
\end{tabular}

Table 1 noticeably indicated that the students' most common error type in their translation was misformation, according to the Surface Strategy Taxonomy, followed by addition and omission. At last, the least common form of error committed by students was misordering.

\section{Results of the questionnaire related to the causes of errors}

Based on the responses of the questionnaire, the finding shows five possible causes in this study; problems in the target language, mother-tongue interference, lack of eagerness to learn the target language, lack of confidence, and the absence of error feedback from the teacher. The results of each question are displayed in the form of pie charts in the figures below after the questionnaires have been submitted.

What are your difficulties in applying English's structure or grammar when you write in English?

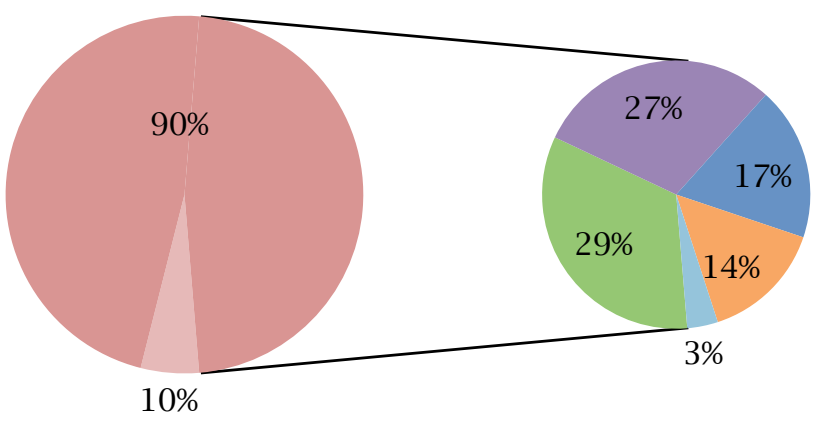

- Do not have difficulties

- Have difficulties

— Difficult in vocabulary

- Difficult in tenses

- Difficult in grammar

- Confusing

$\square$ Difficult in memorizing

Figure 1. The results of the questionnaire related to the problems in the target language 


\section{When you translate the sentences, do you translate them word by word based on the sentence order of your first language? If so, why did you do it?}

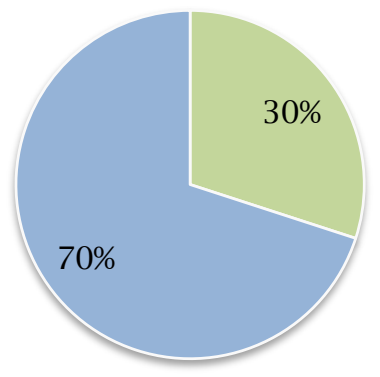

- Translate to Indonesian

- Translate to English

Figure 2. The results of the questionnaire related to mother-tongue interference

\section{Does your teacher provide error feedback? \\ If so, how does the teacher provide it?}

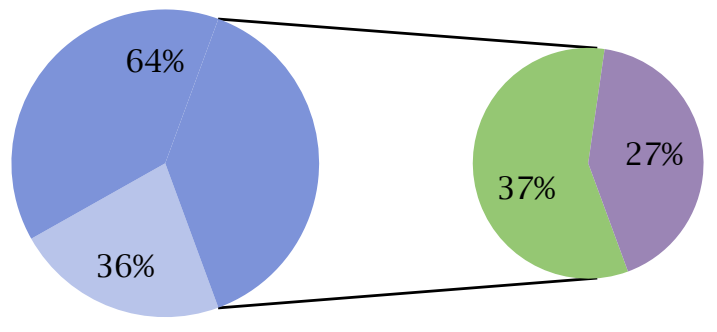
Does not provide error feedback
- Provide error feedback
By showing and correcting the errors
- Only showing the errors

Figure 3. The results of the questionnaire related to the error feedback from teacher

\section{How do you learn in writing English sentences?}

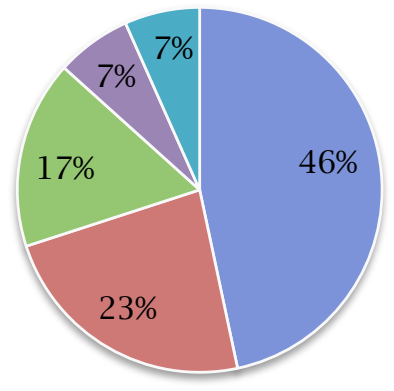
- At school with the help of teachers and textbooks
- By looking at the dictionary
By practicing on my own
- With the help from others
घy watching films, listening to the music, and reading a book

Figure 4. The results of the questionnaire related to the eagerness to learn the target language 
Are you afraid or not confident when writing in English? If so, what makes you afraid of writing English? If no, what makes you confident in writing English?

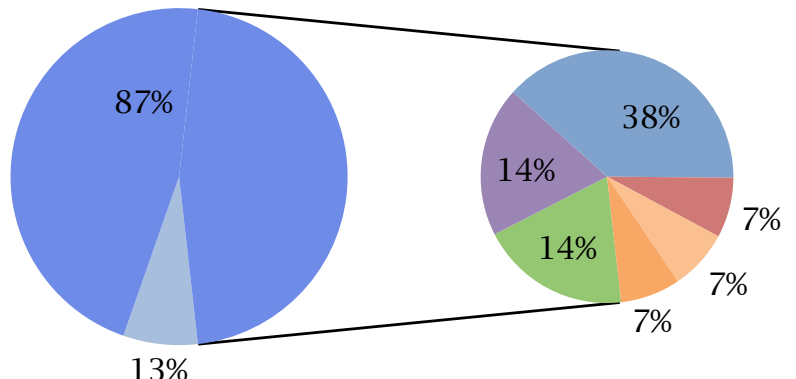
Confident
Not confident
Difficult in grammar
- Difficult in vocabulary
Afraid to make errors
Difficult in tenses
Unfamiliar with English
- Confusing

Figure 5. The results of the questionnaire related to confidence

Do you think the sentences you made are correct?

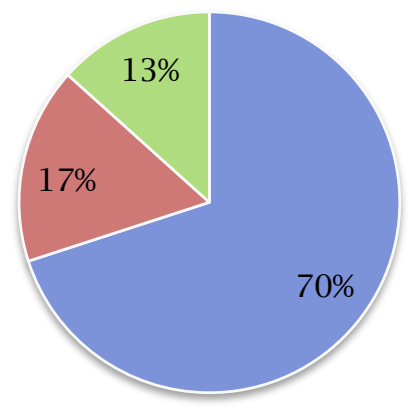
- The students did not realize their sentences were incorrect
- The students realized their sentences were incorrect
- The students confused by their sentences

Figure 6. The results of the questionnaire related to students' awareness of committing errors

\section{Discussion}

The findings of a recent study were discussed in this section. It demonstrates how the students made mistakes with grammar components and how their mistakes could be categorised into Surface Strategy Taxonomy types of errors. The following discussion extends on the example to show how those points could be addressed.

\section{Students' grammatical errors in terms of surface strategy taxonomy}

The students committed errors in their recount text translation in all types of Surface Strategy Taxonomy: omission, addition, misformation, and misordering, according to the findings of this study. This finding supports the previous research by (Handayani, 2018) and (Rosanti, 2019). Their research focuses on the study of grammatical faults in students' narrative and explanatory text translations from Indonesian to English. According to their findings, the students made errors in all aspects of Surface Strategy Taxonomy during their translation. The most common type of error was misformation. The least common errors committed by students were omission, addition, and misordering.

\section{Misformation}

Misformation has the largest percentage, according to Table 1 . This indicates that the majority of the students made this kind of error in their translation. Misformation error is characterised by the use of an incorrect form of morpheme or structure (Dulay et al., 1982). To demonstrate the point below is an example of one of the students' erroneous sentences:

TL: I can spent my time with my family in a beautiful city.

SL: Saya bisa menghabiskan waktu saya dengan keluarga saya di kota yang indah. 
The above sentence is generally wrong because the verbs are arranged incorrectly. It should be 'could spend' because, according to English grammar rules, every modal verb should be followed by the base form of the verb. This implies that the students were unaware of the change of specific verbs caused by a specific tense or followed by any modal. So the correct statement is I could spend my time with my family in a beautiful city.

\section{Addition}

Addition error is characterised by the presence of an item that must not appear in a well-formed sentence (Dulay et al., 1982). This kind of error accounts for the second-highest percentage of errors, as indicated in Table 1. The error occurred because the students added a useless morpheme in the article, noun, verb, or preposition, and failed to omit auxiliary (is, am, are, was, and were) before the verb. Here is an example of one of the learners' incorrect sentences:

\section{TL: We were really enjoyed it. \\ SL: Kami benar-benar menikmatinya.}

The student combined the auxiliary word 'were' with the main verb 'enjoyed' in the sentence above. Because the sentence contains two primary verbs, the auxiliary verb were should be removed. The students' errors in addition were caused by a misunderstanding of the use of auxiliary and primary verbs. Therefore, the erroneous sentence should be We really enjoyed it.

\section{Omission}

As shown in Table 1, omission errors are the third most common type of student error. Omission error is characterised by the absence of an item that must appear in a well-formed utterance (Dulay et al., 1982). Most of the students omitted some grammatical items, such as auxiliary verbs, articles ' $a$ ' and 'the', some prepositions, and the students confused using morpheme $-s$ to indicate plural nouns. Here is an example of an erroneous sentence from one of the students:

\section{TL: We not swam because dangerous waves and just playing sand near the beach. \\ SL: Kami tidak berenang karena ombak yang berbahaya dan hanya bermain pasir di dekat pantai.}

In the examples above, the student has failed to make a correct sentence by omitting the auxiliary. The student failed to add auxiliary 'did' before the verb, and omit the preposition after the word because. Then, the appropriate article 'the' should be added before the phrase dangerous waves. Based on the results, the most frequent aspect dealt with article omission. These findings showed that in constructing English sentences, the students committed these errors because mostly they ignored the use of articles. The sentence above should be We did not swim because of the dangerous waves and just played sand near the beach.

\section{Misordering}

Table 1 shows that the students only made small misordering errors in their translation. (Dulay, et al., 1982) state that misordering is characterised by the incorrect placement of a morpheme or a group of morphemes in an utterance. The students tend to follow their first language sentence order when translating the sentences into English specifically when they used adjectives, adverbs, and nouns in a phrase or sentence. The following example illustrates the case of the students' incorrect ordering:

\section{TL: We also saw sunset a very beautiful there. \\ SL: Kami juga melihat matahari terbenam yang sangat cantik di sana.}

In the sentences above, the students made errors in ordering an adjective-noun. The adjective must be used as a modifier before being followed by the noun. It indicated that the student did not understand how to correctly combine many words into a complete sentence. The rules of their first language could influence the students who made these kinds of errors. The sentence should be revised as We also saw a very beautiful sunset there.

\section{Causes of students' errors}

After all the students answered the questionnaire and submitted it, the results revealed that there were five possible causes of students' errors. They were problems in the target language, mother-tongue interference, lack of eagerness to learn the target language, lack of confidence, and the absence of error feedback from the teacher. This 
finding confirmed some previous studies related to the causes of errors. (Cúc, 2018) found mother-tongue interference and the lack of knowledge of the target language as the possible causes of students' translation error. The students' learning styles that are only obtained from the teacher or school and not trying to explore independently can prevent their knowledge to increase and lead to grammatical errors. It is often closely related to a lack of motivation, as (Nik, Sani, et al., 2010) identified that the students are not motivated to improve their writing. Moreover, (Wongranu, 2017) conducted research related to error translation made by English major students and found carelessness as one of the causes of errors including misreading and interference of background knowledge, low self-confidence, and their anxiety. (Al-Khairy, 2018) stated that the students need guidance from their teacher to help them minimise the errors and motivate them to be more active in learning English. The following discussion elaborate on those causes of errors.

\section{Problems in the target language}

After coding the data of the questionnaires that the students had been answered, it could be concluded that students had difficulties in writing English such as difficulty in vocabulary, tenses, and grammar. From the results of students' answers, most of students stated they did not know a lot of English vocabulary, which led them to need extra time when making the sentence. In addition, the students are not familiar with the sentences appropriately. Hence, the students overgeneralised the rules or made their own rules of the target language because of their inability to distinguish between the rules of the source and target languages.

\section{Mother-tongue interference}

Due to the fact that the students used their first language linguistic knowledge rather than the target text linguistic knowledge, this interference caused problems in their translation. The students might believe that the target language and their native language are the same. Because there were certain differences between the source text and the target text, the errors occurred. In translating the text, the students applied word by word translation using their first language structures.

\section{Lack of eagerness to learn the target language}

In learning to write English, almost half of them stated they only learned from what was given by the teacher and the textbook in the school. It indicates that students did not have any will to explore learning the target language to improve their writing skills. This finding deals with (Nik, Sani, et al., 2010), who found that students' errors happened due to the unmotivated students to improve their writing.

\section{Lack of confidence}

In translating the text, the students admitted to having a low level of proficiency and a limited vocabulary. They thought the recount text translation tasks were challenging. They lacked confidence in their ability to complete the tasks and did not put in the extra effort. This result was similar to the previous research done by (Wongranu, 2017), which showed that carelessness, including misreading, low self-confidence, and students anxiety, were the causes of error.

\section{The absence of error feedback from the teacher}

The lack of teacher guidance by providing error feedback also plays an important role in improving students' writing skills. The questionnaire showed some of the students answered that their teachers did not provide any writing error feedback to them. Thus, the students always make the same error continuously since they did not know the correct answer.

\section{Conclusion}

In relation to the research results, most students still committed all error types of Surface Strategy Taxonomy in recount text translation; omission, addition, misformation, and misordering. The most frequent error type the students made was misformation, and the least frequent was misordering. The frequencies of each type of error could be seen in the result chapter. Problems with the target language, mother-tongue interference, a lack of eagerness to learn the target language, a lack of confidence, and the absence of error feedback from the teacher were all possible causes of student translation errors.

Based on the findings, it can be inferred that students had the most difficulties in translating the English vocabulary. Meanwhile, mostly they were able to arrange the sentences correctly. Regarding the causes of those errors, it is clearly stated that students mostly had problems in English, either in the vocabulary or tenses. 
Since this study used Surface Strategy Taxonomy to analyse the errors, it is suggested to the other researchers to analyse errors using the other taxonomies, i.e. Communicative Effect Taxonomy, Linguistic Category and Comparative Analysis Taxonomy. Then, because this study utilised a questionnaire, it is suggested to other researchers that they add some additional items to the questionnaire that the researcher created using the theory of error causes to collect richer data and use different methodologies that do not use a questionnaire.

\section{Acknowledgements}

The authors express gratitude to the school principal, teachers, and first-grade students of SMAN 1 Pringsewu, Lampung Province, Indonesia, for their help and participation in this study.

\section{Funding}

This research received no specific grant from any funding agency in the public, commercial, or not-forprofit sectors.

\section{References}

Anderson, M., \& Anderson, K. (1997). Text types in English 3. South Yarra: MacMillan.

Al-Khairy, M. A. (2013). Saudi English-major undergraduates' academic writing problems: A taif university perspective. English Language Teaching, 6(6), 1-12.

Anjarani, D. R., \& Indahwati, R. (2019). An analysis of students' errors in using simple past tense in translating narrative text. Prosodi, 13(2), 68-74.

Brown, H. D. (2001). Teaching by principles: An interactive approach to language pedagogy (2nd ed.). New York: Addison Wesley Longman.

Catford, J. C. (1965). A linguistic theory of translation. London: Oxford University Press.

Corder, S. P. (1981). Error analysis and interlanguage. Oxford: Oxford University Press.

Cúc, P. T. (2018). An analysis of translation errors: A case study of Vietnamese EFL students. International Journal of English Linguistics, 8(1), 22-29.

Dang, T. N. A. (2019). EFL student's writing skills: Challenges and remedies. IOSR Journal of Research \& Method in Education, 9(6), 74-84.

Dulay, H., Burt, M., \& Krashen, S. (1982). Language two. New York: Oxford University Press.

Ellis, R. (1997). Second language acquisition. New York: Oxford University Press.

Handayani, D. (2018). Students' errors in translating narrative text based on Dulay's surface strategy taxonomy. Medan: University of Medan.

James, C. (2013). Errors in language learning and use. New York: Routledge.

Khoirunida, S. (2019). An analysis of grammatical errors in the translation made by the fourth semester students of English Education Program. JELLT (Journal of English Language and Language Teaching), 3(2), 114-125.

Koman, H. N. N., Hartono, R., \& Yuliasri, I. (2019). Translation errors in students' Indonesian-English translation practice. English Education Journal, 9(2), 206-218.

Kumala, B. P., Aimah, S., \& Ifadah, M. (2018). An analysis of grammatical errors on students' writing. 2nd English Language and Literature International Conference (ELLiC), 2, 144-146.

Larson, M. L. (1998). Meaning based translation: A guide to cross-language equivalence (2nd ed.). New York: University Press of America.

Newmark, P. (1988). A textbook of translation: translating and interpreting. Hertfordshine: Prentice Hall Regents.

Nida, E. A., \& Taber, C. R. (1982). The theory and practice in translation. Leiden: United Bible Societies.

Nik, Y. A., Sani, B. B., Kamaruzaman, M. N. B. W. C., Hasbollah, H. R. B., et al. (2010). The writing performance of undergraduates in the University of Technology, Mara, Terengganu, Malaysia. Journal of Languages and Culture, 1(1), 8-14.

Thornbury, S. (1999). How to teach grammar. Edinburgh: Pearson Education

Ur, P. (1996). A course in language teaching: practice and theory. Cambridge: University Press.

Venuti, L. (1995). A translator's invisibility: A history of translation. New York: Routledge.

Wahyono, M. I. A., \& Yuliasri, I. (2019). Students' translation techniques and grammatical errors in translating narrative text. ELT Forum: Journal of English Language Teaching, 8(1), 1-13.

Wongranu, P. (2017). Errors in translation made by English major students: A study on types and causes. Kasetsart Journal of Social Sciences, 117-122. 